\title{
NUCLEOTIDE SEQUENCE ORGANISATION IN THE WHEAT GENOME
}

\author{
RICHARD B. FLAVELL and DEREK B. SMITH \\ Cytogenetics Department, Plant Breeding Institute, Trumpington, Cambridge CB2 $2 L Q$
}

Received 20. ii.76

\section{SUMMARY}

Chromosomal nucleotide sequence organisation has been studied in hexaploid wheat, Triticum aestivum, using methods based upon the different renaturation kinetics of repeated and non-repeated sequences. Approximately 25 per cent of the wheat genome consists of non-repeated sequences. Nearly two-thirds of these ( 15 per cent of the genome) are around 1000 base pairs long interspersed between repeated sequences. Approximately 7 per cent of the genome consists of non-repeated sequences several thousand base pairs long. Less than 5 per cent of the genome consists of very much longer non-repeated sequences.

Four per cent of the genome consists of extremely rapidly renaturing (foldback?) sequences. These sequences are distributed through at least 20 per cent of the genome.

Between 50 and 65 per cent of the genome consists of repeated sequence DNA which is cleaved to duplexes approximately 400 to 800 base pairs long by $S_{1}$ nuclease after renaturation in vitro. This implies that related repeated sequences frequently have different neighbouring sequences in the chromosomes. Repeated sequences ( 32 per cent of the genome) able to reanneal in very stringent incubation conditions are between approximately 350 and 650 base pairs long and are distributed through 85 per cent of the genome at intervals of less than 4000 base pairs. This distribution implies that short regions of essentially nondiverged repeated sequence DNA are interspersed with longer regions of diverged repeated sequence DNA in the chromosomes. Approximately 10 per cent of the genome appears to consist of very long repeated sequences or of long clusters of short, essentially identical repeated sequences.

\section{InTRODUCTION}

Most hypotheses on the control of gene expression and chromosome behaviour in eucaryotes are currently based upon linear arrays of different kinds of nucleotide sequences (Britten and Davidson, 1969; Paul, 1972; Georgiev et al., 1973; Gierer, 1973; Lewin, 1974). Using electron-microscopical and biochemical methods nucleotide sequence organisation has been investigated in the genomes of a number of organisms including Xenopus (Davidson et al., 1973a, b), sea urchin (Graham et al., 1974), Drosophila (Wu et al., 1972; Kram et al., 1972; Laird et al., 1973; Manning et al., 1975), rat (Bonner, J. et al., 1973) and Dictyostelium (Lodish et al., 1973; Firtel and Kindle, 1975). It appears to be a general finding that much of the DNA of these organisms with the exception of Drosophila (Manning et al., 1975) is composed of non-repeated nucleotide sequences between 700 and 2500 nucleotides long interspersed by shorter repeated sequences (Davidson et al., 1975). Chromosomes of higher organisms also have clusters of inverted duplications or palindrome sequences (Wilson and Thomas, 1974; Bonner, 1974) as well as long regions of tandemly repeated sequences (Walker, 1971; Yunis and Yasmineh, 1971). However, little information on genome organisation is currently available for higher plants. 
In this paper we report on the chromosomal nucleotide sequence organisation of common bread wheat, Triticum aestivum. In earlier studies on the wheat genome (Smith and Flavell, 1975) three classes of DNA were distinguished: (1) a fraction that renatures extremely rapidly and may therefore include regions of the chromosomes containing inverted duplications (see Wilson and Thomas, 1974; Bonner, 1974); (2) a fraction which renatures slowly and appears to contain sequences present in about six copies per hexaploid cell; and (3) the remaining DNA, about 80 per cent of the genome, which reanneals at intermediate rates and consists of repeated sequences with repetition frequencies between 50 and 50,000 per haploid genome. The amounts, lengths and linear arrangements of these different kinds of sequences are investigated in this paper.

\section{MATERIALS AND METHODS}

(i) Isolation of ${ }^{3} \mathrm{H}$-labelled and unlabelled DNAs

Unlabelled wheat, variety Chinese Spring, DNA was isolated from leaves, as described by Smith and Flavell (1974). Tritium-labelled DNA was purified from 3-day-old seedlings germinated in the presence of ${ }^{3} \mathrm{H}$ thymidine $\left(\mathrm{CH}_{3}\right.$-labelled, $41 \mathrm{Ci} / \mathrm{m} \mathrm{mol}$ ) as described previously (Smith and Flavell, 1974.) Specific activity of the DNA was $28430 \mathrm{cpm} / \mu \mathrm{g}$. Purified Xenopus DNA was a gift from Professor H. C. MacGregor, University of Leicester. Calf thymus and $E$. coli DNAs were purchased from Sigma Chemical Co. $98 \pm 1$ per cent of the native DNAs were retained on hydroxyapatite at $60^{\circ} \mathrm{C}$ in $0 \cdot 12-\mathrm{M} \mathrm{PB}$ (phosphate buffer).

\section{(ii) DNA fragmentation and estimation of average fragment sizes}

Different concentrations of DNA in ice-cold 0.12-M PB were sheared by different doses of sonication to a range of average fragment sizes as previously described (Smith and Flavell, 1974, 1975). Weight average single strand fragment lengths of unlabelled DNAs were determined by boundary velocity sedimentation in $0 \cdot 9-\mathrm{M} \mathrm{NaCl} 0 \cdot 1-\mathrm{m} \mathrm{NaOH}$ as described by Studier (1965) using an MSE "Centriscan" analytical ultracentrifuge. It is important to note that although only weight average fragment sizes are mostly quoted in this paper, all DNA preparations, especially those unlabelled DNAs with longer average fragment sizes, were heterogeneous. Distribution curves of the fragment sizes in unlabelled DNA preparations treated with similar doses of sonication have been presented previously (Smith and Flavell, 1975). Estimates of the size of double-stranded duplexes resistant to $S_{1}$ nuclease were determined by boundary sedimentation in 1-M NaCl (Studier, 1965). Tritium-labelled DNAs of different average fragment sizes were obtained by fractionating native DNA in 5 to 11 per cent $\mathrm{w} / \mathrm{w}$ linear sucrose gradients made in $0 \cdot 1-\mathrm{m} \mathrm{NaOH}$ after sedimentation for 19 hours at 24,000 r.p.m. at $20^{\circ} \mathrm{C}$. Weight average single-stranded fragment lengths in each gradient fraction were determined as described by Burgi and Hershey (1963) after sedimentation for 16 to 19 hours in identical gradients. Approximately $1 \mu \mathrm{g}$ of ${ }^{3} \mathrm{H}$-labelled DNA was sedimented together with $150 \mu \mathrm{g}$ unlabelled marker DNA whose molecular weight was determined separately in the analytical ultracentrifuge. Size distribution 
profiles of unlabelled DNAs were derived from the analytical ultracentrifuge curves by the method of Schumaker and Schachman (1957).

We recognise that upon boiling and incubating at $60^{\circ} \mathrm{C}$ some shearing of single-stranded DNA occurs, particularly with longer fragment lengths. In only some experiments (see fig. 3 ) did we make measurements of fragment size after denaturation and incubation. Thus the illustrated longer fragment lengths in many experiments may be overestimates of the sizes actually involved in duplex formation but this does not invalidate any of our general conclusions.

\section{(iii) Renaturation of denatured $D \mathcal{N A}$}

DNAs, at selected concentrations in appropriate solvents, were denatured by heating for 5 to 10 minutes and immediately incubated to the required $\mathrm{C}_{0} \mathrm{t}$ value to allow renaturation. The following incubation conditions were used (1) $0 \cdot 12-\mathrm{M} \mathrm{PB}$ at $60^{\circ} \mathrm{C}$, (2) $0 \cdot 12-\mathrm{m} \mathrm{PB} 0 \cdot 645-\mathrm{M} \mathrm{NaCl}$ at $65^{\circ} \mathrm{C}$ and (3) 62 per cent formamide $0 \cdot 69-\mathrm{M} \mathrm{NaCl}$ at $42 \cdot 5^{\circ} \mathrm{C}$. After incubation under conditions $l$ and 2 the DNA solutions were cooled, diluted with three volumes of ice-cold water and loaded on to hydroxyapatite equilibrated with 0.03-M PB at room temperature. After incubation under condition (3) the DNA solution was cooled and diluted with a 15-fold excess of $0.03-\mathrm{M}$ PB before hydroxyapatite chromatography. The hydroxyapatite columns were washed with $0.03-\mathrm{M} \mathrm{PB}$ at room temperature before single-stranded DNA was eluted with $0 \cdot 12-\mathrm{M} \mathrm{PB}$ at room temperature and $60^{\circ} \mathrm{C}$ and the renatured DNA was eluted with $0.5-\mathrm{M} P B$ first at $60^{\circ} \mathrm{C}$ and then at $95^{\circ} \mathrm{C}$. After incubation in formamide (condition 3) single-stranded DNA was usually eluted at $80^{\circ} \mathrm{C}$ with $0 \cdot 12-\mathrm{M} \mathrm{PB}$ and the renatured DNA at $95^{\circ} \mathrm{C}$ with $0 \cdot 12-\mathrm{M} \mathrm{PB}$. However, elution of single-stranded DNA from hydroxyapatite at $60^{\circ}$ or $70^{\circ} \mathrm{C}$ after incubation under condition 3 gives similar results.

\section{(iv) Estimations of $D \mathcal{N} A$ concentrations}

Unlabelled DNA in the $0 \cdot 12-\mathrm{M}$ PB and $0 \cdot 5-\mathrm{m}$ PB hydroxyapatite column eluates was estimated by $\mathrm{OD}_{260}$ measurements after low-speed centrifugation to sediment any hydroxyapatite. Recoveries of DNA from hydroxyapatite were approximately 100 per cent except when renatured DNAs of large initial average fragment sizes were chromatographed; in these cases a small proportion (less than 7 per cent) could not be removed with $0 \cdot 5-\mathrm{M}$ PB at $95^{\circ} \mathrm{C}$. Reannealed DNA values were corrected for 20 per cent hypochromicity when recovered at $60^{\circ} \mathrm{C}$ (Smith and Flavell, 1975) and for the proportion of the DNA behaving as renatured DNA on hydroxyapatite immediately after boiling (see Davidson et al., $1973 b$ and fig. 5).

Percentages of reannealed DNA were also corrected for any $\mathrm{OD}_{260}$ or tritium in the native DNA preparations which did not adhere to hydroxyapatite at $60^{\circ} \mathrm{C}$ in $0 \cdot 12-\mathrm{M} \mathrm{PB}$.

Tritium-labelled DNA was estimated by precipitation with 5 per cent (final concentration) trichloroacetic acid (TCA) in the presence of 100 to $150 \mu \mathrm{g}$ bovine serum albumin in the cold, collection on Whatman GF/B filters and counting in a scintillation mixture (Smith and Flavell, 1974, 1975). To investigate whether precipitation efficiency or collection efficiency on the filter varied with very different fragment sizes of native, denatured 
or renatured DNAs as suggested by Schrier and Wilson (1973), a series of separate experiments were carried out. Two DNA preparations, one with an average fragment molecular weight of 860,000 daltons and a sheared preparation with an average fragment molecular weight of 82,500 daltons were used. Where required, the DNAs were denatured by adding an equal volume of $1-\mathrm{m} \mathrm{NaOH}$ and neutralising after 15 minutes with four volumes of a solution containing 3-M NaCl, 1-M Tris- $\mathrm{HCl} p \mathrm{H} 8.0$ and $1-\mathrm{N} \mathrm{HCl}$ in the proportions of $2: 1: 1$. DNA precipitation was carried out as described above. The precipitation and collection efficiencies were studied at DNA concentrations of $55 \mu \mathrm{g} / \mathrm{ml}, 17 \mu \mathrm{g} / \mathrm{ml}$ and $1.5 \mu \mathrm{g} / \mathrm{ml}$. The results in table 1 show that estimates of the recovered DNA were independent of the fragment size, concentration and DNA configuration over the ranges essential for many of the experiments described in this paper. This method of estimating ${ }^{3} \mathrm{H}$-labelled DNAs was therefore considered adequate.

TABLE 1

The effect of concentration, denaturation and shearing on the precipitation and recovery of ${ }^{3} \mathrm{H}$-labelled $D \mathcal{N} A$

\begin{tabular}{|c|c|c|c|c|}
\hline & \multicolumn{3}{|c|}{ Final DNA concentrations ${ }^{a}$} & \multirow{2}{*}{$\begin{array}{l}\text { Mean } \mathrm{cpm} \pm \text { standard } \\
\text { error of means }\end{array}$} \\
\hline & $55 \mu \mathrm{g} / \mathrm{ml}$ & $17 \mu \mathrm{g} / \mathrm{ml}$ & $1.5 \mu \mathrm{g} / \mathrm{ml}$ & \\
\hline $\begin{array}{l}\text { Sonicated DNA } \\
\text { Unsonicated DNA } \\
\text { Single-stranded DNA } \\
\text { Double-stranded DNA }\end{array}$ & $\begin{array}{l}7232 \\
7508 \\
7650 \\
7390\end{array}$ & $\begin{array}{l}7848 \\
8022 \\
7908 \\
7962\end{array}$ & $\begin{array}{l}7774 \\
8164 \\
7575 \\
8363\end{array}$ & $\begin{array}{l}7618 \pm 206 \\
7898 \pm 190 \\
7711 \pm 115 \\
7905 \pm 261\end{array}$ \\
\hline $\begin{array}{l}\text { Means cpm } \pm \text { standard } \\
\text { error of means }\end{array}$ & $7423 \pm 246$ & $7935 \pm 213$ & $7969 \pm 225$ & \\
\hline
\end{tabular}

\section{(v) DNA melting curves}

Optical melting curves for DNA eluted from hydroxyapatite or after $\mathrm{S}_{1}$ nuclease digestion were carried out in $0 \cdot 12-\mathrm{M} \mathrm{PB}$ in a $1-\mathrm{cm}$ light path cuvette heated in the spectrophotometer cell holder by circulating ethylene glycol. The temperature was monitored by a thermistor probe in an identical adjacent cell. All samples to be compared were dialysed into the same batch of $0 \cdot 12-\mathrm{M}$ PB before melting.

\section{(vi) $S_{1}$ nuclease digestion}

$\mathrm{S}_{1}$ nuclease was prepared from "Takadiastase" (Koch Light Ltd) by the method of Sutton (1971) and stored in 50 per cent glycerol at $-20^{\circ} \mathrm{C}$. I microlitre of the solution contained 4.6 units of activity where 1 unit degrades $1 \mu \mathrm{g}$ single-stranded DNA to acid soluble material at $25^{\circ} \mathrm{C}$ in 60 minutes (Shishido and Ando, 1972).

Treatment of samples of renatured DNA with $S_{1}$ nuclease was carried out as follows: after renaturation in $0 \cdot 12 \mathrm{~m} \mathrm{~PB}$ at $60^{\circ} \mathrm{C}$ four volumes of cold $0 \cdot 3-\mathrm{M} \mathrm{NaCl}$ and five volumes of assay buffer (Davidson et al., 1973a) were added, the resultant $p \mathrm{H}$ being $4 \cdot 5$. After equilibration to $37^{\circ} \mathrm{C} \mathrm{S}_{1}$ nuclease 
was added and incubation continued for 90 minutes. The appropriate $S_{1}$ concentrations and incubation times were determined in preliminary experiments. The reaction was terminated by rapid cooling and the addition of $0.5 \mathrm{vol} 0 \cdot 12-\mathrm{M}$ PB followed by gentle shaking with an equal volume of chloroform containing 1 per cent octanol. The aqueous layer was separated by centrifugation and applied to a hydroxyapatite column equilibrated with $0.03-\mathrm{M}$ phosphate at room temperature. After washing the column with $0 \cdot 03-\mathrm{M} \mathrm{PB}, 0 \cdot 12-\mathrm{M} \mathrm{PB}$ at room temperature and $0 \cdot 12-\mathrm{m} \mathrm{PB}$ at $60^{\circ} \mathrm{C}$, the $S_{1}$ nuclease resistant DNA duplexes were recovered by elution with $0 \cdot 5-\mathrm{M} \mathrm{PB}$ at $60^{\circ} \mathrm{C}$. In control experiments 97 per cent of native DNA but only 4 per cent of denatured wheat DNA were recovered in the 0.5-M PB fraction after $S_{1}$ nuclease treatment. The 4 per cent $S_{1}$ nuclease-resistant DNA is believed to be the fraction of the genome which reanneals virtually instantaneously after denaturation (see fig. 5; Shishido and Ikeda, 1970; Smith and Flavell, 1975).

\section{Results}

In our previous studies the renaturation kinetics of wheat DNA were investigated using hydroxyapatite chromatography to separate renatured and denatured DNA (Smith and Flavell, 1975). Estimates of the proportions of intermediate reannealing repeated sequence and non-repeated sequence DNAs using hydroxyapatite are dependent upon the linear sequence organisation in the chromosomes. If the non-repeated sequences are short and interspersed between repeated sequences, then even with DNA fragments around 400 nucleotides long, a significant proportion of the non-repeated sequence DNA will be present on duplex-forming fragments when only repeated sequences are allowed to reanneal (Davidson et al., $1973 a, b ;$ Graham et al., 1974). We therefore carried out experiments to investigate the inclusion of non-repeated sequence DNA in the renatured repeated sequence DNA fraction from which conclusions about the size and organisation of non-repeated sequences can be drawn.

(i) The size and organisation of non-repeated sequences-the effect of fragment length on the proportion of $D \mathcal{N} A$ in the in vitro renatured repeated sequence $D \mathcal{N} A$ fraction

Our studies on sequence interspersion are based upon the different renaturation kinetics of repeated and non-repeated sequences. Renaturation kinetics of denatured sheared wheat DNA indicate that almost all the repeated sequence DNA is in the duplex fraction upon incubation to $C_{0} t 50$ while most of the non-repeated sequences do not begin to reanneal until a $\mathrm{C}_{0} \mathrm{t}$ of 500 (Smith and Flavell, 1975). To test whether single or few copy sequences are interspersed with repeated sequences in wheat chromosomes, DNA samples of average single-strand fragment sizes ranging from 200 to 6000 nucleotides were denatured and incubated to $\mathrm{C}_{0} \mathrm{t} 50$. The proportion of the DNA binding to hydroxyapatite in $0 \cdot 12-\mathrm{M}$ PB (phosphate buffer, $0 \cdot 18-\mathrm{M} \mathrm{Na}^{+}$), i.e. the proportion of fragments containing renatured duplex DNA, is shown in fig. 1 for each average fragment size.

The dependence on fragment size of the proportion of DNA renaturing by $\mathrm{C}_{0} \mathrm{t} 92$ was also studied using ${ }^{3} \mathrm{H}$-labelled DNA fragments with average sizes ranging from 150 to 8800 nucleotides. In these experiments the 


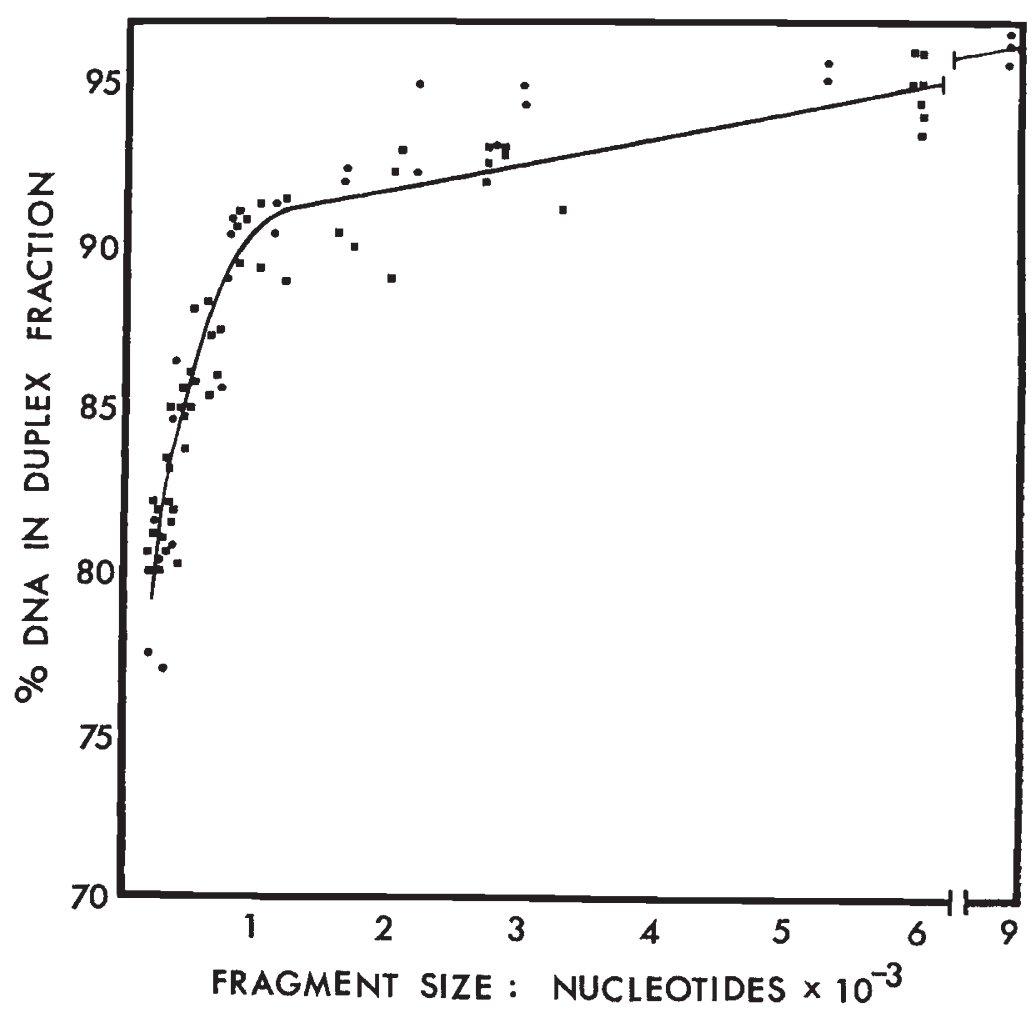

FIG. 1.-The effect of fragment length on the proportion of DNA in the in vitro renatured repeated sequence DNA fraction.

(a) With unlabelled DNAs of different sizes ( $\boldsymbol{\square}$ ). Aliquots of unlabelled DNA at $300 \mu \mathrm{g} /$ $\mathrm{ml}$ were sonicated in $0 \cdot 12 \mathrm{M}$ phosphate buffer to yield samples with average denatured fragment sizes from 200 to 6000 nucleotides. Aliquots of each sample were denatured, incubated at $60^{\circ} \mathrm{C}$ to $\mathrm{C}_{0} \mathrm{t} 50$ and the proportion in the renatured DNA fraction determined by hydroxyapatite chromatography. In separate experiments (unpublished), the proportion of DNA in the renatured DNA fraction between $\mathrm{C}_{0} \mathrm{t} 20$ and 200 was examined using various sizes of fragments. For a given fragment size, the increase in the renatured DNA fraction between $\mathrm{C}_{0} \mathrm{t} 20$ and 200 was less than 5 per cent. Thus even though different size fragments renature at different rates (Wetmur and Davidson, 1968) and thus effectively to a different $\mathrm{C}_{0} \mathrm{t}$ value, this has little effect on the results presented in this figure.

(b) With labelled DNAs of different sizes ( ). Tritium-labelled DNAs of average fragment sizes from 150 to 8800 nucleotides were added to aliquots of unlabelled DNA $(400 \mu \mathrm{g} / \mathrm{ml})$ in $0 \cdot 12-\mathrm{M}$ phosphate buffer, average fragment size 460 nucleotides. The ratios of labelled to unlabelled DNA were between $1: 750$ and $1: 3000$. After melting and incubating to $\mathrm{C}_{0} \mathrm{t} 92$ at $60^{\circ} \mathrm{C}$ the proportions of ${ }^{3} \mathrm{H}$-labelled DNA in the renatured DNA fractions were determined by hydroxyapatite chromatography. The proportions of ${ }^{3} \mathrm{H}$-labelled DNA are corrected for the DNA binding to hydroxyapatite immediately after denaturation (Davidson et al., 1973b).

labelled DNA was incubated with a 750- to 3000-fold excess of unlabelled "driver" DNA of average fragment size of approximately 460 nucleotides. The rationale behind this experimental design is described by Davidson et al. $(1973 b)$. The proportion of each size of labelled DNA involved in duplex formation with unlabelled " driver " DNA was estimated by hydroxyapatite chromatography. These results are also shown in fig. 1. The results 
of both kinds of experiments are essentially the same; the proportion of DNA in the renatured fraction increases considerably more rapidly with fragments shorter than approximately 1000 nucleotides than with fragments longer than 1000 nucleotides.

An increase in the proportion of renatured DNA, retained by hydroxyapatite at $0 \cdot 12-\mathrm{M}$ phosphate, with increasing DNA fragment size is due to single-stranded non-repeated sequence DNA attached to reannealed repeated sequence DNA (Davidson et al., 1973b). The lengths of these single-stranded DNA " tails" increase with starting fragment size. The relatively abrupt change in slope in fig. 1 around 1000 nucleotides indicates that approximately 15 per cent of the wheat genome (estimated from extrapolation to the $y$ axis) consists of single or few copy sequences, around 1000 nucleotides long or less, interspersed between repeated sequences which form stable duplex DNA by $\mathrm{C}_{0} \mathrm{t} 50 / 92$ in $0 \cdot 18-\mathrm{M} \mathrm{Na}{ }^{+}$at $60^{\circ} \mathrm{C}$. The 2 or 3 per cent of the DNA not retained on hydroxyapatite, even when relatively long fragments ( $>9000$ nucleotides) are incubated to $\mathrm{C}_{0} \mathrm{t} 50 / 92$, must consist either of long non-repeated sequences distantly spaced from a repeated sequence or of denatured DNA unable to take part in stable duplex formation for some reason.

Davidson et al. (1973b) have reported that a small fraction (5-8 per cent) of the repeated sequence DNA of Xenopus fails to form a stable duplex after one incubation at $60^{\circ} \mathrm{C}$ in $0 \cdot 18-\mathrm{M} \mathrm{Na}^{+}$(perhaps due to spurious involvement in a poor duplex structure which cannot bind to hydroxyapatite), but does form a stable duplex on a second incubation with more repeated sequence DNA. If this occurs with wheat DNA, all the DNA might be included in the duplex fraction on hydroxyapatite with fragments longer than 9000 nucleotides and we would have no evidence for very long nonrepeated sequences in wheat. The 6 or 7 per cent of additional DNA included in the duplex fraction on hydroxyapatite with average fragment lengths between 1000 and 9000 nucleotides, probably consists of nonrepeated sequences several thousand nucleotides long interspersed between repeated sequences.

Extrapolation of the curve in fig. 1 to very small fragments which would consist either of non-repeated or repeated sequences but not both, indicates that approximately 75 per cent of the wheat genome consists of repeated sequences able to form stable duplexes at $60^{\circ} \mathrm{C}$ in $0 \cdot 18-\mathrm{M} \mathrm{Na}{ }^{+}$by $\mathrm{C}_{0} \mathrm{t} 50$.

\section{(ii) The size and organisation of repeated sequences}

If repeated sequences in a genome are relatively short, their length can be estimated by determining the continuous lengths of duplex DNA that are present after renaturation of long fragments in vitro (Davidson $e t$ al., 1973a). Discontinuities in duplex DNA arise when renatured repeated sequences, which are substantially shorter than the fragments, are adjacent to non-repeated or different repeated sequences in the genome. Such single-stranded discontinuities are illustrated in fig. 2A, C, D, E and F.

Single stranded DNA associated with renatured repeated sequence DNA fragments is degraded by the single-stranded DNA nuclease $S_{1}$ from Aspergillus (Ando, 1966; Sutton, 1971; Graham et al., 1974). However, the degree to which this enzyme recognises mismatched bases in reannealed 


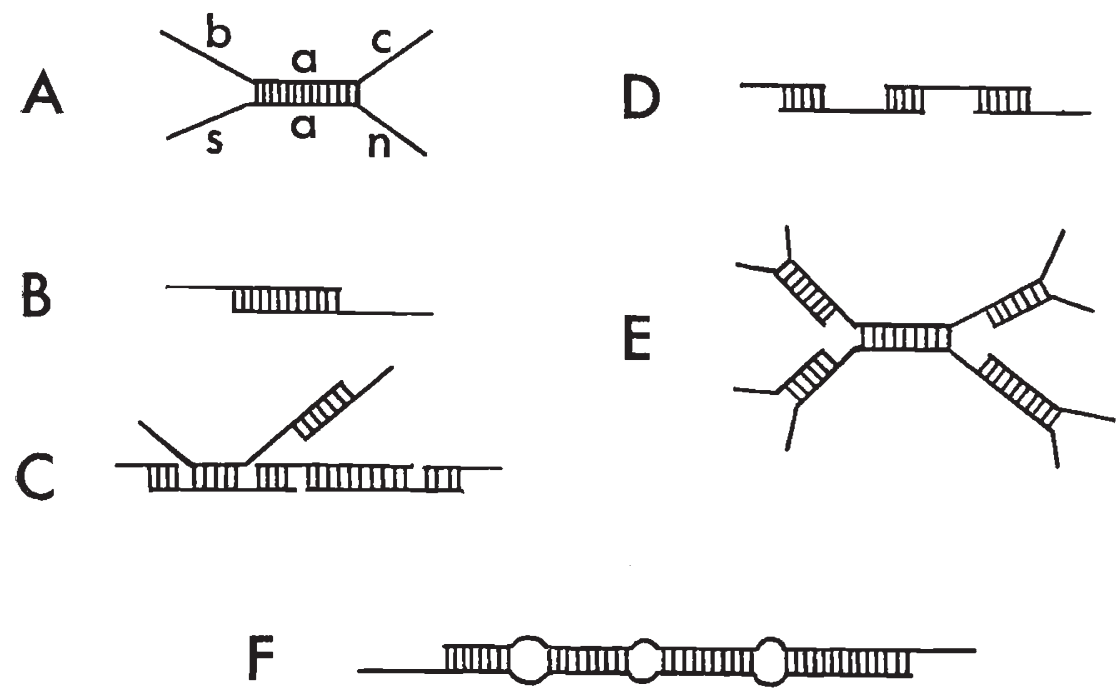

FIG. 2.-Different kinds of renatured DNA configurations. A, A duplex with four unrenatured tails which would form when renatured repeated sequences labelled $a$ came from different places in the genome and had different neighbouring sequences; $b$ and $c$ on one fragment and $s$ and $n$ on the other fragment. B, A duplex with two unrenatured tails. This duplex would form when the fragments were portions of much longer homologous sequences. C, A multifragment duplex showing how branched structures can be formed in a predominantly linear arrangement. The hybridisations have occurred such that some of the single strand gaps are very small. D, A multifragment duplex where hybridisations have occurred leaving large single-stranded gaps. E, A multifragment duplex involving hybridisations between sequences on long fragments which are not homologous throughout their entire length. F, A duplex formed between long fragments which are only partially homologous. The non-homology could have arisen as a result of mutations within a long cluster of sequences which were originally identical.

repeated sequences, in addition to single stranded regions, is dependent upon the salt concentration and temperature of the assay mixture. We therefore chose $0 \cdot 15-\mathrm{M} \mathrm{Na}^{+}$and $37^{\circ} \mathrm{C}$ as incubation conditions since in these conditions only single-stranded or grossly mismatched regions are degraded (Davidson et al., 1973a). Most of the reannealed duplexes with a moderate degree of mismatching are left intact (Bonner, 1974).

DNA samples were sheared to several different average fragment sizes, denatured and incubated to $\mathrm{C}_{0}$ t 50 in $0 \cdot 12-\mathrm{M} \mathrm{PB}$ at $60^{\circ} \mathrm{C}$ and then half of each sample was incubated with $\mathrm{S}_{1}$ nuclease. Double-stranded duplexes were recovered from the $S_{1}$ nuclease treated and untreated samples by hydroxyapatite chromatography. Independent of the initial fragment size, the proportion of the genome that renatured to form $S_{1}$ nuclease resistant duplexes was $55 \pm 2$ per cent. This is consistent with the increasing proportion of DNA included in the renatured DNA fraction with increasing fragment size being single stranded DNA (see fig. l). Optical melting curves of the $S_{1}$ resistant duplexes were indistinguishable, irrespective of the starting average fragment size of the DNA molecules. The hyperchromicities of the $S_{1}$ resistant duplexes were approximately 21 per cent of the final optical density after melting. Native DNA hyperchromicity was 25 per cent. Since the $\mathrm{T}_{\mathrm{m}}$ of the duplexes was $10^{\circ} \mathrm{C}$ below that of native 
DNA, the duplexes were mismatched by about 6 per cent on average (Ullman and McCarthy, 1973).

The results in fig. 1, as indicated earlier, show that some 75 per cent of wheat DNA is repeated sequence DNA. However, since only 55 per cent of the DNA is resistant to $S_{1}$ nuclease after renaturation to $C_{0} t 50$, approximately 20 per cent of the repeated sequence DNA must have been degraded by $S_{1}$ nuclease after renaturation to $\mathrm{C}_{0} t 50$. Much of the degraded repeated sequence DNA was probably unrenatured "tails" of duplexes. When randomly sheared fragments collide and nucleation occurs in vitro, on average less than two-thirds of each fragment is base paired; the rest remains as denatured "tails", as illustrated in fig. $2 \mathrm{~B}$, and is degraded by $\mathrm{S}_{1}$ nuclease (Smith et al., 1975). Where the renaturing repeated sequence length is considerably shorter than the average fragment length, as in experiments with many animal DNAs, the single-stranded $S_{1}$ susceptible DNA "tails" consist mainly of non-repeated sequence DNA which is interspersed with most of the repeated sequence DNA (Davidson et al., 1973a; Graham et al., 1974). Thus in these situations not much of the repeated sequence DNA is degraded by $S_{1}$ nuclease after repeated sequence DNA renaturation. However, with genomes where long regions of repeated sequence DNA occur, as in wheat, many of the "tails" of primary duplexes must consist of repeated as well as non-repeated sequence DNA. Repeated sequence DNA will thus be degraded by $\mathrm{S}_{1}$ nuclease. Some secondary nucleations involving repeated sequence "tails" do occur with wheat DNA incubated to $\mathrm{C}_{0} \mathrm{t} 50$ (see later), protecting the "tails" from $\mathrm{S}_{1}$ nuclease digestion, as illustrated in fig. $2 \mathrm{E}$, but these are insufficient to involve all the repeated sequence "tails" of the primary duplexes unless very long fragments are used. Furthermore, all of each "tail" is not always protected from $S_{1}$ nuclease by secondary nucleations. This explanation of the digestion of repeated sequence DNA by $S_{1}$ nuclease is supported by the observation that 15 to 20 per cent of renatured $E$. coli DNA binding to hydroxyapatite at $0 \cdot 12-\mathrm{M}$ phosphate is degraded by $\mathrm{S}_{1}$ nuclease under similar conditions.

Although much of the $S_{1}$ nuclease degraded wheat repeated sequence DNA was probably unrenatured " tails" of duplexes, some also consisted of very mismatched duplexes formed between diverged repeated sequences, since the melting curves of $\mathrm{S}_{1}$ resistant duplexes show less DNA melting between $60^{\circ}$ and $65^{\circ} \mathrm{C}$.

The average size of the $\mathrm{S}_{1}$ nuclease resistant wheat duplexes was determined by velocity sedimentation in a number of experiments. Aliquots of denatured DNA, sonicated to different lengths, were incubated to $\mathrm{C}_{0}$ t 50 at $60^{\circ} \mathrm{C}$ in $0 \cdot 18-\mathrm{M} \mathrm{Na}^{+}$and treated with $\mathrm{S}_{1}$ nuclease. The double-stranded DNA was dialysed to $1-\mathrm{M} \mathrm{NaCl}$ and run in the analytical ultracentrifuge. The size of the $\mathrm{S}_{1}$ nuclease resistant duplexes of Xenopus and E. coli DNAs, treated in an identical way, were also studied in parallel experiments to serve as comparative controls. Xenopus DNA has previously been characterised by Davidson $e l$ al. $(1973 a, b)$. The weight average denatured fragment sizes of the incubated DNAs were determined after denaturation and incubation to $\mathrm{C}_{0} \mathrm{t} 50$, to take account of any single-strand bieakage during denaturation and/or incubation at $60^{\circ} \mathrm{C}$. The results for wheat, E. coli and Xenopus DNAs are shown in fig. 3.

With $E$. coli $\mathrm{DNA}$, the average $\mathrm{S}_{1}$ nuclease resistant duplex size after 


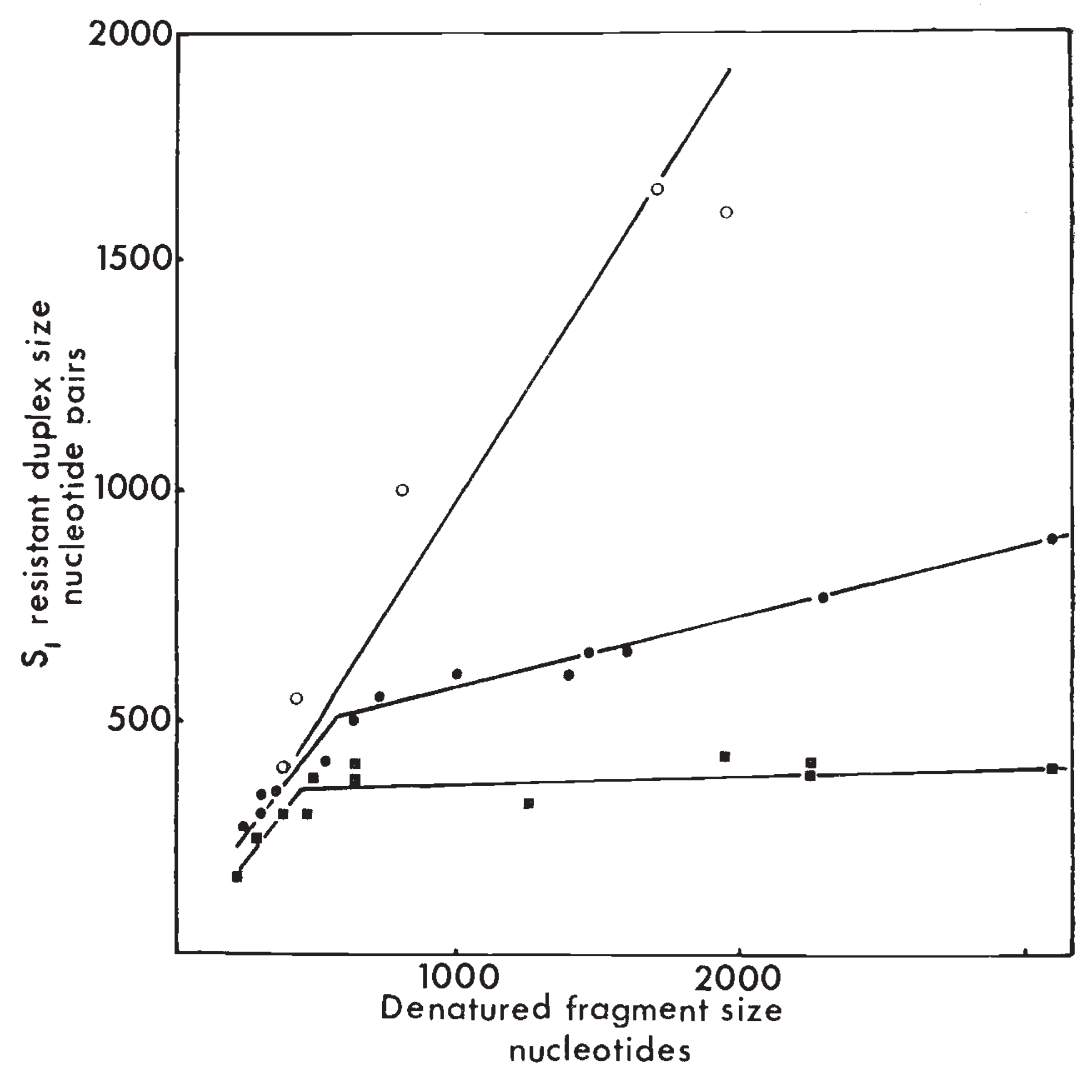

FIG. 3.- The relationships between the weight average size of the $S_{1}$ nuclease resistant duplexes and the weight average single-strand fragment size present during duplex formation. Samples of wheat, Xenopus and E. coli DNAs, $370 \mu \mathrm{g} / \mathrm{ml}$ in $0 \cdot 12-\mathrm{M}$ phosphate buffer, were sonicated to various average fragment sizes. After denaturation and incubation at $60^{\circ} \mathrm{C}$ in $0 \cdot 12-\mathrm{M}$ phosphate buffer to $\mathrm{C}_{0} \mathrm{t} 50$ (wheat and Xenopus) or $\mathrm{C}_{0} \mathrm{t} 119$ (E. coli) half of each sample was used to gain the average single-stranded fragment sizes present during duplex formation. The other half was treated with $S_{1}$ nuclease, the $S_{1}$ nuclease resistant duplexes recovered by hydroxyapatite chromatography, dialysed extensively against $1-\mathrm{M} \mathrm{NaCl}$ and the average size of the duplexes determined in the analytical ultracentrifuge.

Wheat.

Xenopus. $\bigcirc$ E. coli.

renaturation of over 90 per cent of the DNA was similar to the starting fragment size over the whole range of fragment sizes studied. However, on denaturation the $S_{1}$ nuclease resistant duplexes yielded fragments considerably smaller than the starting fragment size. For example, in an experiment where fragments on average 2000 nucleotides long were incubated to a $\mathrm{C}_{0}$ t of 119 , the $\mathrm{S}_{1}$ nuclease resistant duplexes had an average length of 1625 nucleotide pairs. After alkali denaturation these duplexes yielded fragments with an average length of 880 nucleotides. Thus many of the $S_{1}$ nuclease resistant duplexes in the renatured DNA must be constructed of more than two single-stranded fragments and have some singlestrand gaps within the double helices that are too short to be recognised by $S_{1}$ nuclease under our assay conditions. Such a duplex structure is illustrated in fig. 2c. It is formed from multiple hybridisation events. 
When larger single-strand gaps occur in multifragment duplex structures (see fig. 2D) or when there are only two fragments per duplex (see fig. 2A), $\mathrm{S}_{1}$ nuclease would degrade the single-stranded regions leaving the duplexes shorter than the starting single-stranded fragments. Therefore, where the average $S_{1}$ nuclease resistant duplex length was found to be similar to or greater than the average starting fragment length in fig. 3 , the reductions in duplex length caused by $S_{1}$ nuclease were presumably compensated by the presence of longer $S_{1}$ nuclease resistant duplexes involving more than two fragments, as illustrated in fig. $2 \mathrm{C}$.

Whereas the average size of the $S_{1}$ nuclease resistant duplexes was similar to the starting fragment size over the whole range of fragment sizes studied in E. coli, with Xenopus DNA this was so only up to a weight average duplex size of around 350 nucleotide pairs. This is what could be expected from the known differences in sequence organisation between $E$. coli and Xenopus. Approximately 55 per cent of the Xenopus genome consists of short non-repeated sequences alternating with repeated sequences about 300 nucleotides long and a further 35 per cent consists of very long non-repeated sequences (Davidson et al., 1973a,b). With this alternating sequence organisation most of the duplex regions would be expected to be only 300 nucleotide pairs long after renaturation of 2000 nucleotide long fragments to $\mathrm{C}_{0} \mathrm{t} 50$, which allows only repeated sequences to reanneal. The single copy sequences separating the short repeated sequences should remain denatured and therefore be digestible by $S_{1}$ nuclease.

The size distribution of Xenopus $\mathrm{S}_{1}$ nuclease resistant duplexes after renaturation of 3100 and 2200 nucleotide long fragments is shown in fig. 4 . This distribution was derived by the method of Schumaker and Schachman (1957) from the sedimentation behaviour of the duplexes in the analytical ultracentrifuge. As expected, most of the duplexes (20 per cent of the genome) were between 300 and 500 nucleotides long although some (about 6 per cent of the genome) were much longer. These results are in good agreement, therefore, with those expected from the chromosome model of Davidson et al. $(1973 a, b)$.

With wheat DNA the weight average $S_{1}$ nuclease resistant duplex size was similar to the weight average size of the starting denatured DNA fragments up to a length of 500 nucleotides, i.e. longer than in Xenopus. The size distribution of $S_{1}$ nuclease resistant duplexes after renaturation of wheat DNA fragments around 2900 nucleotides to $\mathrm{C}_{0} \mathrm{t} 50$, is shown in fig. 4. Most of the duplexes are between 400 and 800 nucleotides long. Together, the results for wheat DNA in figs. 3 and 4 imply that after renaturation of long single-stranded DNA molecules to $\mathrm{C}_{0} \mathrm{t} 50$, effectively single-stranded regions occur at each end of reasonably well-matched duplex regions, a large proportion of which are between 400 and 800 nucleotides long. This is what would be expected, based on the interpretation of the Xenopus results, if much of the $S_{1}$ nuclease resistant fraction of renatured wheat DNA consisted of repeated sequences between 400 and 800 nucleotides long. However, repeated sequences of this length could not always be separated by non-repeated sequence DNA as in Xenopus, since in wheat we have shown above that only 15 to 20 per cent non-repeated sequence DNA is interspersed in 75 per cent repeated sequence DNA. Furthermore, we have illustrated with $E$. coli DNA (and with small wheat and Xenopus DNA fragments) that where fragments consist entirely of 


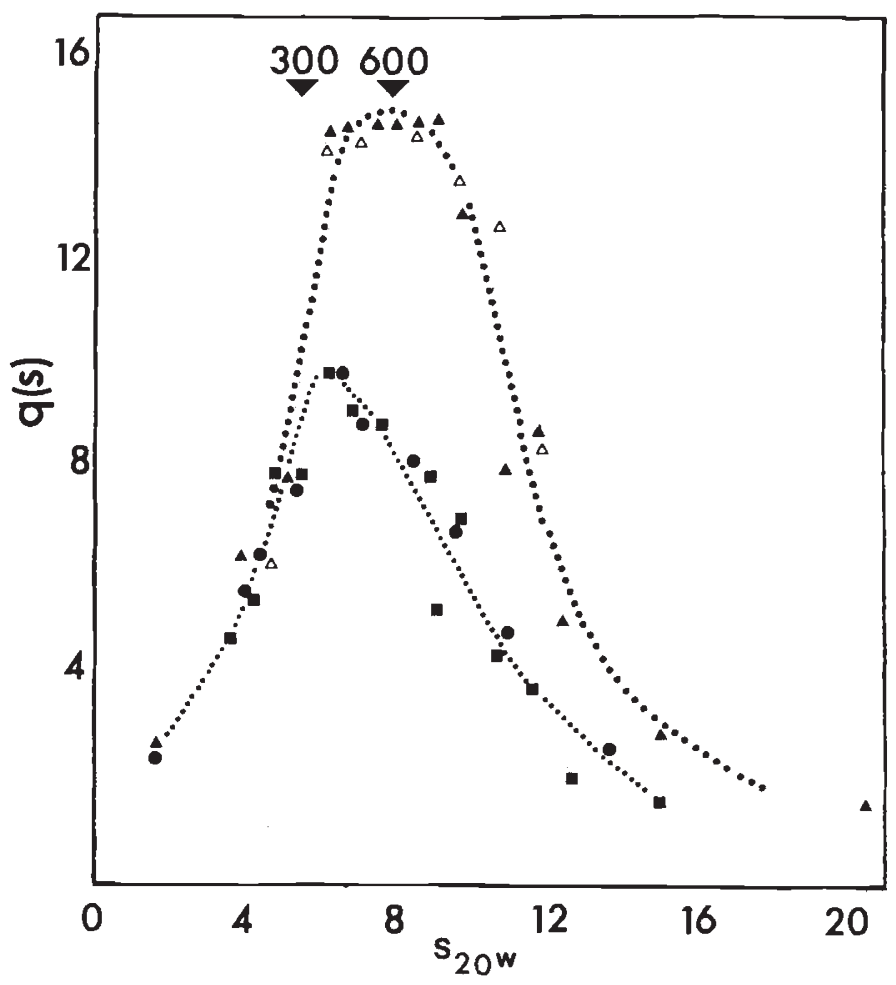

FIG. 4.-Distribution of sizes of $\mathrm{S}_{1}$ nuclease resistant duplexes formed in vitro between repeated sequences. Results are from two different experiments. Distributions were calculated from the boundary sedimentation profiles in the analytical ultracentrifuge by the method of Schumaker and Schachman (1957). Average single-stranded fragment size before denaturation and incubation were 3100 (O) and 2200 (口) nucleotides for Xenopus and $3000(\triangle)$ and $2800(\mathbf{\Delta})$ nucleotides for wheat.

$$
q(s)=\frac{100}{C_{\mathrm{obs}}} \times \frac{d C_{\mathrm{obs}}}{d S_{20} W},
$$

where $C_{\mathrm{obs}}=$ observed concentration (see Schumaker and Schachman, 1957). Arrows indicate duplex lengths in nucleotide pairs.

sequences able to renature under the incubation conditions, $S_{1}$ nuclease resistant duplexes, as long or longer than the starting fragments, form readily. Why then are nearly all wheat DNA duplexes cleaved by $S_{1}$ nuclease to give duplexes between 400 and 800 nucleotides long after incubation of fragments with an average starting size of around 2900 nucleotides, many of which must consist entirely of repeated sequence DNA?

We suggest that the high number of $S_{1}$ nuclease sensitive sites in reannealed wheat duplexes is due to closely related repeated sequences having different neighbouring sequences at different places in the genome. This would lead on renaturation of long fragments either to duplexes with four "tails", as illustrated in fig. 2, A and E, if the neighbouring sequences were entirely unrelated or, if the neighbouring sequences were partially related, to duplexes with regions of extensive base mismatching as illustrated in fig. 2, F. The "tails" in fig. 2, $\mathrm{A}$, the branch nodes in fig. 2, $\mathrm{E}$ and the mismatched regions in fig. $2, \mathrm{~F}$ would be sensitive to $S_{1}$ nuclease. 
The reduction in slope of the wheat DNA curve above 500 nucleotides to 15 per cent of the slope with starting fragments shorter than 500 nucleotides in fig. 3 , implies that most of the DNA fragments are cleaved by $S_{1}$ nuclease after renaturation. This suggests that the interspersion of short non-repeated sequences and of different kinds of repeated sequences occurs throughout most of the chromosomes. However, the presence of a 15 per cent slope implies that some repeated sequences renature to form $S_{1}$ nuclease resistant duplexes much longer than 800 nucleotide pairs. We estimate from the size distribution curve of $S_{1}$ nuclease resistant wheat duplexes in fig. 4 that about 20 per cent of the duplex DNA is considerably longer than 800 nucleotide pairs. The DNA in this distribution curve represents 55 per cent of the genome. We therefore estimate that approximately 10 per cent of the wheat genome consists of repeated sequences which renature to form long $S_{1}$ nuclease resistant duplexes. (The 20 per cent repeated sequence DNA in the genome which is degraded by $S_{1}$ nuclease after in vitro duplex formation (see above), is more likely to consist of the short interspersed repeated sequences than of the long repeated sequences.) The long duplexes in fig. 4 presumably consist either of repeated sequences several thousand nucleotides long or of short repeated sequences, arranged in the chromosomes such that multifragment duplexes with few $S_{1}$ nuclease digestible regions can form in vitro.

\section{(iii) Binding of denatured wheat DNA to hydroxyapatite}

Wheat DNA, in common with DNA from many other higher organisms (Wilson and Thomas, 1974; Bonner, 1974; Cech and Hearst, 1975), includes a fraction which renatures immediately after denaturation, even at very dilute DNA concentrations. We have already published some experiments describing this wheat fraction (Smith and Flavell, 1975). Recently we have re-studied the proportion of ${ }^{3} \mathrm{H}$-labelled wheat DNA of different average fragment lengths retained by hydroxyapatite as duplex DNA in the presence of $25 \mu \mathrm{g} / \mathrm{ml}$ calf thymus DNA after denaturation by boiling or by alkali treatment and immediately forcing through hydroxyapatite. The estimated $\mathrm{C}_{0} \mathrm{t}$ value for the wheat DNAs was less than $2 \times 10^{-7}$. These experiments differ from those previously reported since the wheat DNA concentration was much lower in the experiments reported here.

The relationship between the proportion of DNA retained by hydroxyapatite as duplex DNA and the average fragment size is shown in fig. 5 . The increase in DNA in the duplex fraction is approximately linear with increasing fragment size and the line intersects the $y$ axis at about 4 per cent.

DNA binding to hydroxyapatite immediately after denaturing has been found in several other organisms to contain "hairpin" structures which form due to inverted duplications (palindromes) being present on the same fragment (Wilson and Thomas, 1974; Bonner, 1974). In wheat also, most of the 4 per cent instantly renatured fraction could consist of such hairpin structures (Huguet, Jouanin and Bazetoux, 1975). The additional DNA associated with these structures in long fragments probably exists as single stranded "tails". This is supported by the very low hyperchromicity of such DNA and the fact that it is degraded by $S_{1}$ nuclease (Smith and Flavell, 1975). 


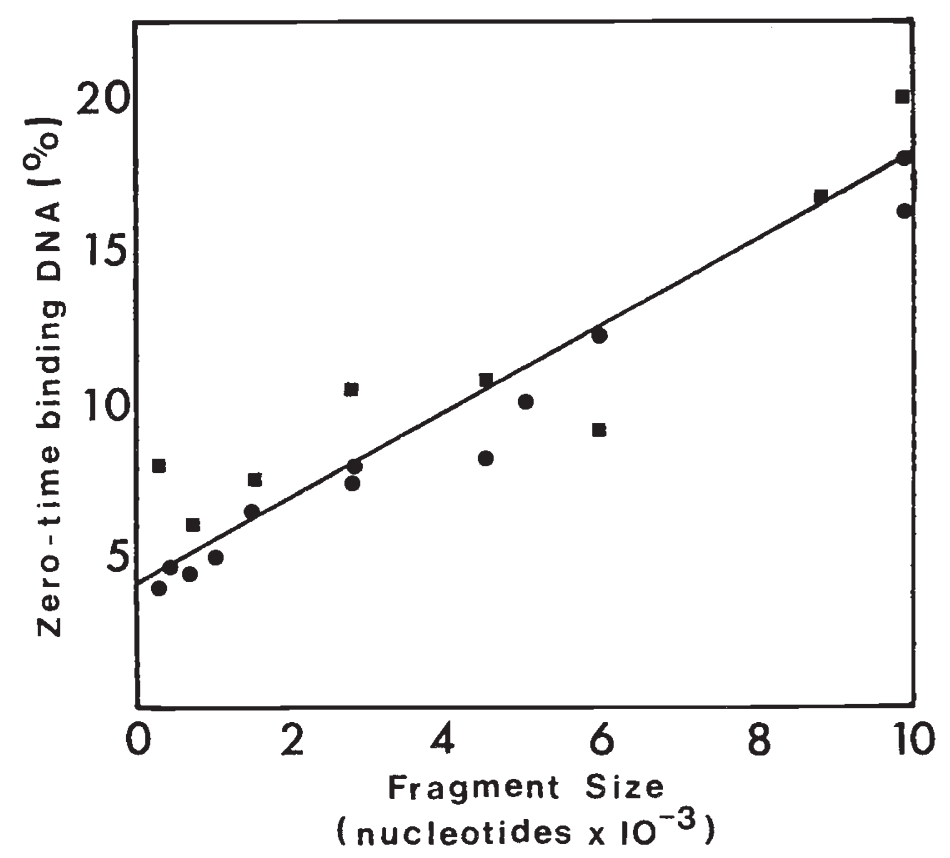

FIG. 5.-The proportion of denatured wheat DNAs of different average fragment sizes behaving on hydroxyapatite as duplex DNA. Two methods of DNA denaturation were used: heat denaturation; alkali denaturation. In heat denaturation experiments, ${ }^{3} \mathrm{H}$-labelled wheat DNAs of various average single stranded fragment sizes ranging from $<200$ to $>10,000$ nucleotides were mixed with calf thymus DNA (average single stranded fragment size $=300$ nucleotides) in $0 \cdot 12-\mathrm{M}$ phosphate buffer such that the final concentration of labelled DNA was $0 \cdot 025 \mu \mathrm{g} / \mathrm{ml}$ and of unlabelled DNA was $25 \mu \mathrm{g} / \mathrm{ml}$. $2 \mathrm{ml}$ aliquots were heated to $100^{\circ} \mathrm{C}$ for 3 minutes and immediately passed through hydroxyapatite equilibrated with $0 \cdot 12$ - phosphate buffer at $60^{\circ} \mathrm{C}$. After rapid washes with $0 \cdot 12-\mathrm{M}$ phosphate buffer at $60^{\circ} \mathrm{C}$ the renatured DNA was recovered by elution with $0 \cdot 5-\mathrm{M}$ phosphate buffer. In alkali denaturation experiments ${ }^{3} \mathrm{H}$-labelled wheat DNAs of various fragment sizes were mixed with calf thymus DNA to give final concentrations of labelled DNA of $0.02 \mu \mathrm{g} / \mathrm{ml}$ and of unlabelled DNA to $20 \mu \mathrm{g} / \mathrm{ml}$. $2.5 \mathrm{ml}$ aliquots were heated to $60^{\circ} \mathrm{C}$ and mixed with 0.11 vols of $1-\mathrm{M} \mathrm{NaOH}$. After 10 minutes the solution was neutralised with 0.55 vols of $0.318-\mathrm{M} \mathrm{NaH}_{2} \mathrm{PO}_{4}$ at $60^{\circ} \mathrm{C}$ and immediately fractionated on hydroxyapatite as described above. The incubation times before fractionation in these experiments were estimated to produce $\mathrm{C}_{0} \mathrm{t}$ values for the wheat DNA of less than $2 \times 10^{-7}$.

From the theory described by Hamer and Thomas (1974) the results in fig. 5 indicate that the instantly renaturing sequences in wheat appear to be clustered into groups, as in some other organisms (Wilson and Thomas, 1974), with the groups distributed throughout at least 20 per cent of the genome. However, we have no more direct evidence at present for clustering of the instantly renaturing sequences.

\section{(iv) The arrangement of diverged repeated and non-repeated sequences between non-diverged repeated sequences}

From the increasing proportion of renatured wheat DNA bound to hydroxyapatite with increasing fragment size after incubation to $\mathrm{C}_{0}$ t $50 / 92$ (fig. 1) it was concluded that approximately 75 per cent of the genome 
consists of repeated sequences. These repeated sequences form duplexes in vitro with a range of thermal stabilities (Smith and Flavell, 1974, 1975), indicating that some repeated sequences are identical, or nearly so, and therefore form very stable duplexes while other repeated sequences are less closely related and form less stable duplexes. For convenience we have called identical or nearly identical repeated sequences " non-diverged repeated sequences" and the less closely related repeated sequences "diverged repeated sequences". These terms were chosen on the assumption that all sequences sufficiently related to form stable duplexes at $60^{\circ} \mathrm{C}$ in $0 \cdot 18-\mathrm{M} \mathrm{Na}^{+}$have originated from the same ancestral sequence.

To investigate the size and arrangement of the diverged and nondiverged repeated sequences, denatured wheat DNA was incubated in 62 per cent formamide $0 \cdot 69-\mathrm{M} \mathrm{NaCl}$ at $42 \cdot 5^{\circ} \mathrm{C}$. These incubation conditions are considerably more stringent than $0 \cdot 18-\mathrm{M} \mathrm{Na}^{+}$at $60^{\circ} \mathrm{C}$. They approximate to $80^{\circ} \mathrm{C}$ in $0 \cdot 18-\mathrm{M} \mathrm{Na}^{+}$(McConaughty et al., 1969; Bendich and McCarthy, 1970) and allow only identical or nearly identical sequences to reanneal. A 700- to 3000-fold excess of denatured, unlabelled DNA, of average fragment size 300 nucleotides, was incubated to $\mathrm{C}_{0} \mathrm{t} 90$ with ${ }^{3} \mathrm{H}$-labelled DNA of average fragment sizes ranging from 180 to $>12,000$ nucleotides. The renatured DNA fractions were separated on hydroxyapatite in $0 \cdot 12-\mathrm{M} \mathrm{PB}$ at $80^{\circ} \mathrm{C}$ although similar results are obtained if the fractionation is carried out at $60^{\circ} \mathrm{G}$. The proportion of ${ }^{3} \mathrm{H}$-labelled DNA included in the renatured DNA fraction with each fragment size is shown in fig. 6 . The proportion increased from approximately 40 per cent with fragments 200 nucleotides long to 85 per cent with fragments 4000 nucleotides long. With fragments longer than 4000 nucleotides there was very little increase in the proportion of the genome included in the duplex fraction on hydroxyapatite.

Incubation of different sized $E$. coli DNA fragments under the high stringency conditions to $\mathrm{C}_{0} \mathrm{t}$ of 90 and fractionation on hydroxyapatite at $80^{\circ} \mathrm{C}$ produced quite different results (see fig. 6). There was very little decrease in the proportion of DNA in the duplex fraction on hydroxyapatite with short fragments. This is what would be expected with DNA which renatures to form duplexes with virtually no mismatched bases. Such duplexes are stable at $80^{\circ} \mathrm{C}$ in $0 \cdot 18-\mathrm{M} \mathrm{Na}^{+}$.

Thirty-two per cent of the wheat DNA was found to be resistant to $\mathrm{S}_{1}$ nuclease after renaturation of long fragments (4000 nucleotides) in 62 per cent formamide $0 \cdot 69-\mathrm{M} \mathrm{NaCl}$ at $42 \cdot 5^{\circ} \mathrm{C}$. This value agrees with the value gained from extrapolation of the curve in fig. 6 to the $y$ axis indicating that the duplexes forming under these conditions are short compared with the starting fragment length of 4000 nucleotides (see earlier). Thus approximately 32 per cent of the wheat genome consists of repeated sequence regions able to form perfect or nearly perfect duplexes after reannealing in vitro and these regions are distributed throughout 85 per cent of the genome at intervals of less than 4000 nucleotides. That the additional 53 per cent associated with the reannealed DNA with long fragments consists of single-stranded tails is confirmed by the finding that it is completely digested by $\mathrm{S}_{1}$ nuclease. Comparison of figs. 1 and 6 indicates that approximately 43 per cent (75-32) of the wheat genome consists of repeated sequence DNA sufficiently diverged to renature as non-repeated sequence DNA in 62 per cent formamide $0.69-\mathrm{M} \mathrm{NaCl}$ at $42 \cdot 5^{\circ} \mathrm{C}$. 


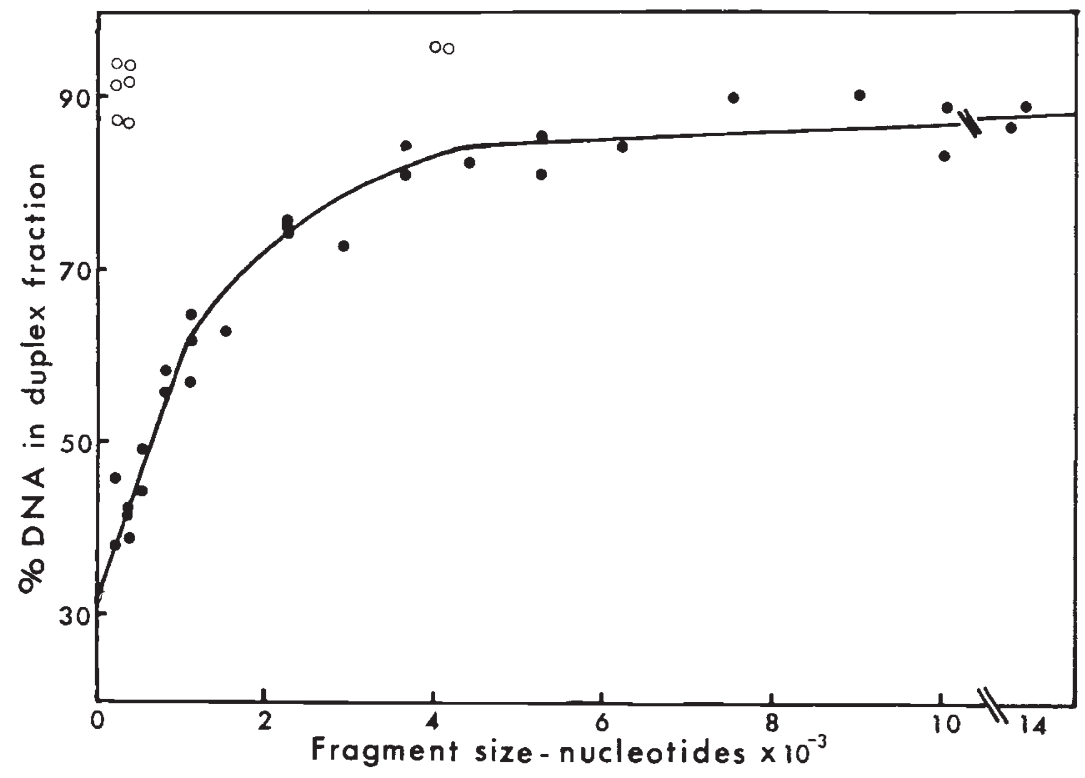

FIG. 6.-The dependence on fragment size of the proportion of DNA included in the renatured DNA fraction on hydroxyapatite after incubation to $\mathrm{C}_{0} \mathrm{t} 90$ in 62 per cent formamide $0 \cdot 69-\mathrm{M} \mathrm{NaCl}$ at $42 \cdot 5^{\circ} \mathrm{C}$. Tritium-labelled wheat DNAs of average singlestranded sizes from 180 to $>12,000$ nucleotides were added to aliquots of unlabelled wheat DNAs (average single stranded fragment size $=300$ nucleotides) to give solutions containing 62 per cent formamide, $0.69-\mathrm{M} \mathrm{NaCl}$ and ratios of labelled to unlabelled DNAs of $1: 700$ to $1: 3000$. Tritium-labelled $E$. coli DNAs of average fragment sizes of $220,360,4000$ and 4150 nucleotides were also mixed with a 1000 -fold excess of unlabelled $E$. coli DNA (average single stranded fragment size $=220$ nucleotides) to give solutions containing 62 per cent formamide $0 \cdot 69-\mathrm{M} \mathrm{NaCl}$. After denaturation by heating to $85^{\circ} \mathrm{C}$ for 3 minutes the DNA solutions were incubated at $42.5^{\circ} \mathrm{C}$ to a $\mathrm{C}_{0} \mathrm{t}$ of 90 . At this $\mathrm{C}_{0} t$ value essentially all the $E$. coli $\mathrm{DNA}$ and all the wheat repeated sequence DNA able to reanneal under these conditions is included in the hydroxyapatite duplex fraction while wheat single copy DNA does not reanneal until a $\mathrm{C}_{0} \mathrm{t}$ value in excess of 500 (unpublished results and Bendich and McCarthy, 1970). After incubation, the samples were diluted with $0.03-\mathrm{M}$ phosphate buffer at $3^{\circ} \mathrm{C}$ and fractionated on hydroxyapatite; renatured DNA was separated from single stranded DNA at $80^{\circ} \mathrm{C}$ in $0 \cdot 12-\mathrm{M}$ phosphate buffer. Wheat. $\bigcirc E$. coli. The point where the extrapolated wheat curve reaches the $y$ axis ( 32 per cent) is that fraction of the wheat DNA that is resistant to $S_{1}$ nuclease after incubation in these conditions.

After renaturation of 4000 nucleotide long fragments at $60^{\circ} \mathrm{C}$ in $0 \cdot 18-\mathrm{M}$ $\mathrm{Na}^{+}$, approximately 95 per cent of the genome was included in the duplex fraction on hydroxyapatite (fig. 1), while after renaturation of similar size fragments in 62 per cent formamide $0 \cdot 69-\mathrm{M} \mathrm{NaCl}$ at $42 \cdot 5^{\circ} \mathrm{C}$ approximately 85 per cent of the genome was included in the duplex fraction. The 10 per cent of the genome not included after incubation and fractionation in the more stringent conditions probably consists of sequences located thousands of nucleotides from sequences able to form stable duplexes at $80^{\circ} \mathrm{C}$ in $0 \cdot 18-\mathrm{M}$ $\mathrm{Na}^{+}$. Alternatively this 10 per cent could represent a fraction of repeated sequences which did not form a stable duplex during the single incubation but would on a second incubation with more repeated sequences (see Davidson et al., 1973b). 
Linear extrapolation of the central portion of the curve in fig. 6 involving 1000 to 4000 nucleotide long fragments, gives an intercept on the $y$ axis of about 50 per cent. From this comes the estimate that about 18 per cent of the wheat genome (50-32 per cent) consists of sequences approximately 1000 nucleotides long which reside between repeated sequences able to form near-perfect duplexes in vitro. These 1000 nucleotide long sequences must be either non-repeated sequences or diverged repeated sequences interspersed between repeated sequences (see fig. 1). From other experiments, which we will describe in detail elsewhere, it appears that at least some of the non-repeated sequences, 1000 nucleotides long or less, lie adjacent to the repeated sequences able to form perfect duplexes in vitro.

The additional DNA (32 per cent) included in the duplex fraction with DNA fragments between 1000 and 4000 nucleotides long after incubation under the high stringency conditions (see fig. 6) must consist of sequences 2000 to 4000 nucleotides long which fail to form well-matched duplexes in vitro, but which reside between repeated sequences able to form nearperfect duplexes in vitro.

\section{(v) The sizes of the non-diverged repeated sequences}

Estimates of the sizes of the repeated sequences able to form nearperfect duplexes in vitro were gained by incubating denatured DNA, with an average fragment size of 2250 nucleotides in 62 per cent formamide $0 \cdot 69-\mathrm{M} \mathrm{NaCl}$ at $42.5^{\circ} \mathrm{C}$ to a $\mathrm{C}_{0} \mathrm{t}$ of 90 , recovering the $\mathrm{S}_{1}$ nuclease resistant duplexes and sedimenting the duplexes in the analytical ultracentrifuge. The weight average fragment size was 570 nucleotides and the distribution of sizes derived from an ultracentrifuge trace of the sedimenting duplexes is shown in fig. 7. We have also included for comparison in fig. 7 a distribution curve of a preparation of rat liver DNA fragments all $380 \pm 20$ nucleotides long. Nearly all the wheat $S_{1}$ nuclease resistant duplexes formed under the high stringency incubation conditions appear to be between 350 and 650 nucleotides long. Thus the 30 per cent non-diverged repeated sequences in the wheat genome are nearly all between 350 and 650 nucleotides long. The broader distribution profile of the wheat DNA compared with that of the rat liver DNA indicates there is size heterogeneity in the wheat $\mathrm{S}_{1}$ nuclease resistant fraction. However, there does not appear to be a substantial proportion of non-diverged repeated sequence duplexes longer than 800 nucleotide pairs. From the equivalent distribution curve of total repeated sequence duplexes (fig. 4) it was estimated that 20 per cent were considerably longer than 800 nucleotide pairs. It therefore appears likely that most of the long-repeated sequences are from families with more sequence heterogeneity or which have a high $\mathrm{A}-\mathrm{T}$ content and are thus unstable at $80^{\circ} \mathrm{C}$ in $0 \cdot 18-\mathrm{M} \mathrm{Na}{ }^{+}$.

\section{Conclusions}

We have summarised our findings on the different kinds of sequences in the wheat genome in fig. 8. The proportion of the wheat genome consisting of repeated sequence DNA is approximately 75 per cent from fig. 1 . This is a considerably higher proportion than found in other genomes analysed in similar detail, e.g. Xenopus (Davidson et al., 1973a,b), sea urchin 


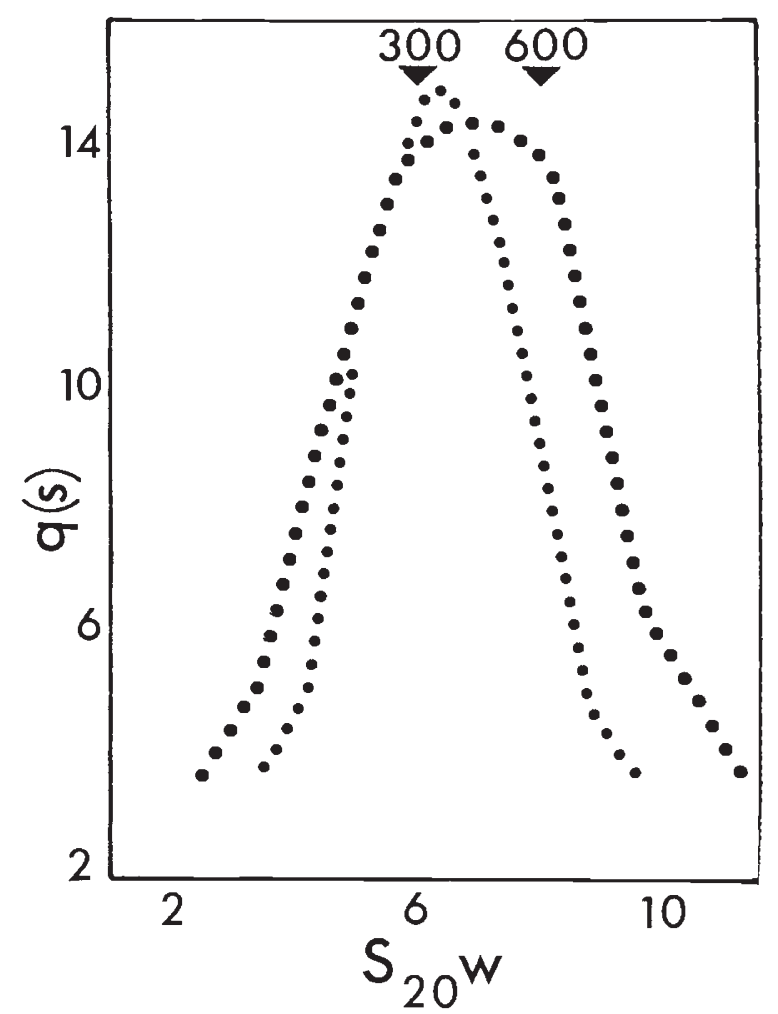

Frg. 7.-Distribution of sizes of $\mathrm{S}_{1}$ nuclease resistant near-perfect duplexes formed in vitro between repeated sequences.

Wheat $S_{1}$ nuclease resistant duplexes.

Rat liver DNA control consisting of fragments $380 \pm 20$ nucleotides. This rat liver DNA preparation was a gift from Dr M. Noll, Medical Research Council's Laboratory of Molecular Biology, Cambridge. It was prepared by incubating rat liver chromatin with micrococcal nuclease and isolating the 380 nucleotide DNA fragments formed by preparative electrophoresis on polyacrylamide (see Noll, 1974). Wheat DNA, average fragment size 2250 nucleotides, was incubated in 62 per cent formamide, $0.69-\mathrm{M} \mathrm{NaCl}$ at $42 \cdot 5^{\circ} \mathrm{C}$ to a $\mathrm{C}_{0}$ t of 90 , treated with $\mathrm{S}_{1}$ nuclease and the renatured fraction recovered on hydroxyapatite. The $\mathrm{S}_{1}$ resistant duplexes were dialysed against 1-M NaCl before being sedimented in 1-M NaCl in the ultracentrifuge. The distributions were calculated from boundary sedimentation profiles of the analytical ultracentrifuge by the method of Schumaker and Schachman (1957). The average denatured fragment size of the wheat DNA after denaturation and incubation, but before $S_{1}$ nuclease treatment was 1900 nucleotides.

$$
q(s)=\frac{100}{C_{\mathrm{obs}}} \times \frac{d C_{\mathrm{obs}}}{d S_{20} W},
$$

where $C_{\mathrm{obs}}=$ observed concentration (see Schumaker and Schachman, 1957). Arrows indicate duplex lengths in nucleotide pairs.

(Graham et al., 1974), Drosophila melanogaster (Laird et al., 1973), rat (Bonner et al., 1973) and Dictyostelium (Lodish et al., 1973). However, the haploid nuclear DNA content of wheat $(6 \mathrm{pg})$ is larger than those of all these other species. Xenopus, for example has a haploid DNA content of $3 \cdot 1 \mathrm{pg}$. We have previously reported that large amounts of repeated sequence DNA are common in higher plant species, especially those with higher DNA 
contents (Flavell et al., 1974). Straus (1971) has reported large proportions of repeated sequence DNA in amphibians with high DNA contents. Thus large amounts of nuclear DNA in plants appear to have resulted in part from sequence amplification as well as from polyploidy and chromosome duplication (Stebbins, 1971; Flavell et al., 1974).

Instantly renaturinga

(inverted duplications? 4\%)

Wheat DNA minus instantly renaturing DNA $^{b}$

Wheat DNA $(100 \%)$

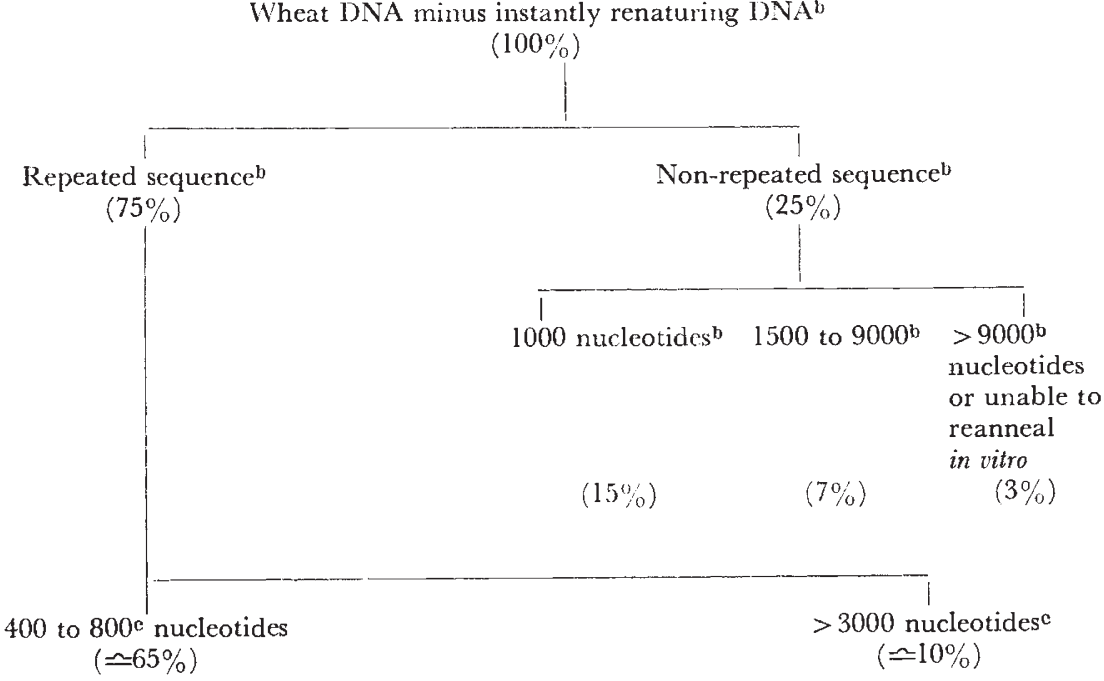

FIG. 8.- Summary of wheat genome fractionation. (a) Behaves as double-stranded DNA immediately after denaturing. (b) Amounts of repeated and non-repeated sequence DNAs are calculated from fig. 1 the results of which are corrected for instantly renaturing DNA. (c) These sizes are estimated from the $\mathrm{S}_{1}$ nuclease resistant duplex size distribution curve in fig. 4 . It was assumed that the 20 per cent repeated sequence DNA degraded by $S_{1}$ nuclease and therefore not included in the size distribution in fig. 4 consisted of the repeated sequences 400-800 nucleotides long. About half of the 400 to 800 nucleotide long sequences ( 32 per cent of genome) form essentially perfect duplexes in 62 per cent formamide $0 \cdot 69-\mathrm{M} \mathrm{NaCl}$ at $42 \cdot 5^{\circ} \mathrm{C}$.

\section{(i) $\mathcal{N}$ on-repeated sequence $D \mathcal{N A}$}

Approximately 20 to 25 per cent of the wheat genome behaved as nonrepeated sequence DNA in renaturation at $60^{\circ} \mathrm{C}$ in $0 \cdot 18-\mathrm{M} \mathrm{Na}{ }^{+}$. Much of this renatures with kinetics expected for sequences present in one or two copies per haploid genome (see Smith and Flavell, 1975). A small amount ( 3 per cent) may consist of non-repeated sequences located many thousands of nucleotides from a repeated sequence or this fraction may simply reflect repeated sequence DNA fragments unable to form stable duplexes (see Results). However, most of the non-repeated sequence DNA is present on fragments also containing repeated sequences when the average fragment size exceeds 1000 nucleotides. Thus most of the non-repeated sequences 
of the wheat genome appear to be around 1000 nucleotides long and interspersed between repeated sequences.

It is not possible to be precise about the size distribution of the interspersed non-repeated sequences from these experiments. The considerable change in slope in fig. 1 at around 1000 nucleotides certainly indicates a population of non-repeated sequences with a restricted size distribution around 1000 nucleotides; more data must be gained from other methods, e.g. electron microscopy.

The shape of the curve in fig. 1 also suggests that 6 or 7 per cent of the genome may consist of much larger interspersed non-repeated sequences up to 9000 or so nucleotides long. In most other organisms examined in similar detail so far, non-repeated sequences 800 to 2500 nucleotides long, interspersed between short, e.g. 300 nucleotide, repeated sequences are also common (Davidson et al., 1975). Non-repeated sequences around 800 to 2500 nucleotides long would be the kinds of sequences expected to code for proteins and this has led to the attractive hypothesis that the functional unit of all eucaryotic chromosomes consists of a repeated sequence(s) associated with a non-repeated coding sequence; the repeated sequence having some role in the control of gene transcription (Britten and Davidson, 1969; Crick, 1971; Paul 1972; Georgiev et al., 1973; Gierer, 1973). Such a model may be appropriate for wheat, but it would be surprising to us if most of the large proportion of repeated sequence DNA in the chromosomes were directly involved in gene regulation.

Although perhaps only 15 per cent of the wheat genome consists of interspersed non-repeated sequences around 1000 nucleotides long, this amounts to about $1.0 \mathrm{pg}$ of DNA per haploid genome which is many times the haploid DNA content of Drosophila melanogaster. Thus there is presumably ample DNA in the interspersed non-repeated sequence fraction of wheat to programme a plant through its life-cycle.

\section{(ii) Repeated sequence $D \mathcal{N} A$}

Of the 75 per cent repeated sequence DNA it is likely that only a small proportion (e.g. 10 to 15 per cent) consists of very long repeated sequences or long clusters of essentially identical repeated sequences, although we have no good direct estimates of this. After renaturation of 3000 nucleotide long fragments in vitro most of the repeated sequence DNA can be cleaved into units mostly between 400 and 800 nucleotides long by $S_{1}$ nuclease acting essentially as a single-stranded DNA specific nuclease. We interpret this to imply interspersion of different repeated sequences in many parts of the genome with closely related repeated sequences often having different repeated sequences as neighbours. We cannot distinguish between the alternatives (1) that the different neighbouring repeated sequences are entirely unrelated, as implied in fig. 2, $\mathrm{E}$, and (2) that the differing neighbouring sequences are diverged members of the same family of repeated sequences, as implied in fig. 2, F. However, it is clear that short regions of non-diverged repeated sequences are interspersed in longer regions of diverged repeated sequences. We plan to discuss the alternatives of repeated sequence DNA arrangements more fully in another paper where more results on the fine structure of the wheat genome gained from a different approach will be presented (Rimpau, Smith and Flavell, in preparation). 
Acknowledgments. - We wish to thank Mr Michael O'Dell for his excellent technical assistance and Drs Jurgen Rimpau and Colin Law for useful discussions and help in the preparation of the manuscript. We are grateful to Professor H. C. MacGregor of the University of Leicester and Dr M. Noll of the Medical Research Council's Laboratory of Molecular Biology, Cambridge, for gifts of DNA samples.

\section{REFERENCES}

ANDo, T. 1966. A nuclease specific for heat-denatured DNA isolated from a product of Aspergillus oryzae. Biochim. Biophys. Acta, 114, 158-168.

BENDICH, A. J., AND MCCARTHY, в. J. 1970. DNA comparisons among barley, oats, rye and wheat. Genetics, 65, 545-566.

Bonner, J., Garrard, W. T., GotTesfeld, J., holmes, D. S., sevall, J. S., AND Wilkes, M. 1973. Functional organisation of the mammalian genome. Cold Spr. Harb. Symp. quant. Biol., $38,303-310$.

BONNER, T. I. 1974. Hairpin-forming sequences in mammalian DNA. Carnegie Inst. Wash. Year Book, 73, 1079-1088.

BRITTEN, R. J., AND DAvidson, E. H. 1969. Gene regulation for higher cells; a theory. Science, $165,349-357$.

BURGI, E., AND HERSHEY, A. D. 1963. Sedimentation rate as a measure of molecular weight of DNA. Biophysical F., 3, 309-321.

CECH, T. R., AND HEARST, J. E. 1975. An electron microscopic study of mouse foldback DNA. Cell, 5, 429-446.

GRICK, F. H. C. 1971. General model for the chromosome of higher organisms. Nature, 234, $25-27$.

Davidson, E. H., GAlAU, G. A., ANGerer, R. C., AND britten, R. J. 1975. Comparative aspects of DNA organisation in Metazoa. Chromosoma (Berl.), 51, 253-259.

DAVidson, E. H., GRAham, D. E., NeUfeld, B. R., Ghamberlin, M. E., AMENSON, C. S., hough, B. R., AND BRITTEN, R. J. 1973a. Arrangement and characterisation of repetitive sequence elements in animal DNAs. Cold Spr. Harb. Symp. quant. Biol., 38, 295-302.

DAVIDSON, E. H., HOUGH, B. R., AMENSON, C. s., AND BRITTEN, R. J. 1973b. General interspersion of repetitive with non-repetitive sequence elements in the DNA of Xenopus. 7. molec. Biol., 77, 1-23.

FIRTEL, R. A., AND KINDLE, K. 1975. Structural organization of the genome of the cellular slime mold Dictyostelium discoideum: Interspersion of repetitive and single copy DNA sequences. Cell, 5, 401-411.

Flavell, R. B., BenNett, M. D., SMIth, J. в., AND smith, D. в. 1974. Genome size and the proportion of repeated nucleotide sequence DNA in plants. Biochem. Genet., 12, 257 269.

GeORGiev, G. P., VARShavsky, A. J., RYSKov, A. P., AND CHURGH, R. B. 1973. On the structural organisation of the transcriptional unit in animal chromosomes. Cold Spr. Harb. Symp. quant. Biol., 38, 869-884.

GIERER, A. 1973. Molecular models and combinational principles in cell differentiation and morphogenesis. Cold Spr. Harb. Symp. quant. Biol., 38, 951-961.

GRAHAM, D. E., NEUFELD, B. R., DAVIDSON, E. H., AND BRITTEN, R. J. 1974. Interspersion of repetitive and non-repetitive DNA sequences in the sea urchin genome. Cell, 1, 127139.

hamer, D. H., AND thomas, C. A., JR. 1974. Palindrome theory. J. molec. Biol., 84, 139 144.

HUGUet, T., JOUANin, L., AND BAzETOUx, s. 1975. Occurrence of palindromic sequences in wheat DNA. Plant Science Lett., 5, 379-385.

KRAM, R., вотсHAM, M., AND HEARST, J. E. 1972. Arrangement of the highly reiterated DNA sequences in the centric heterochromatin of Drosophila melanogaster. Evidence for interspersed spacer DNA. 7. molec. Biol., 64, 103-117.

LAIRD, C. D., GHOOI, W. Y., COHEN, E. H., DICKSON, E., HUTCHINSON, N., AND TURNER, S. H. 1973. Organisation and transcription of DNA in chromosomes and mitochondria of Drosophila. Cold Spr. Harb. Symp. quant. Biol., 38, 311-327.

LEWIN, B. 1974. Sequence organisation of eucaryotic DNA: Defining the unit of gene expression. Cell, 1, 107-111.

LODISH, H. F., FIRTEL, R. A., AND JACOBSON, A. 1973. Transcription and structure of the genome of the cellular slime mold Dictyostelium discoideum. Cold Spr. Harb. Symp. quant. Biol., 38, 899-914. 
MANNING, J. E., SCHMID, C. W., AND DAVIDSON, N. 1975. Interspersion of repetitive and nonrepetitive DNA sequences in the Drosophila melanogaster genome. Cell, 4, 141-155.

MCCONAUGHTY, B. C., LAIRD, C. D., AND MCCARTHY, B. J. 1969. Nucleic acid reassociation in formanide. Biochemistry, 8, 3289-3295.

NOLL, M. 1974. Subunit structure of chromatin. Nature, 251, 249-251.

PAUL, J. 1972. General theory of chromosome structure and gene activation in eucaryotes. Nature, 238, 444-446.

SCHRIER, B. K., AND WILSON, S. H. 1973. Investigation of methods for measurement of radioactivity in tritiated DNA and applications to assays for DNA polymerase activity. Analytical Biochem., 56, 196-207.

SCHUMAKER, V. N., AND SCHACHMAN, H. K. 1957. Ultracentrifugal analysis of dilute solutions. Biochem. Biophys. Acta, 23, 628-639.

SHISHIDO, K., AND ANDO, T. 1972. Estimation of the double-helical content in various single stranded nucleic acids by treatment with a single strand-specific nuclease. Biochem. Biophys Acta, 287, 477-484.

SHISHIDO, K., AND IKEDA, Y. 1970. Some properties of the polynucleotide segments isolated from heat-denatured DNA by digestion with a nuclease specific for single stranded DNA. 7. Biochem., Tokyo, 67, 755-765.

SMITH, M. J., BRITTEN, R. J., AND DAVIDSON, E. H. 1975. Studies on nucleic acid reassociation kinetics: Reactivity of single-stranded tails in DNA-DNA renaturation. Proc. nat. Acad. Sci. (USA), 72, 4805-4809.

SMIrH, D. B., AND FLAVELL, R. B. 1974. The relatedness and evolution of repeated nucleotide sequences in the genomes of some Gramineae species. Biochem. Genet., 12, 243-256.

SMITH, D. B., AND FLAVELL, R. B. 1975. Characterisation of the wheat genome by renaturation kinetics. Chromosoma (Berl.), 50, 223-242.

stebbins, G. L. 1971. Chromosomal Evolution in Higher Plants. Arnold, London.

straus, N. A. 1971. Comparative DNA renaturation kinetics in amphibians. Proc. nat. Acad. Sci. (U.S.A.), 68, 799-802.

STUDIER, F. w. 1965. Sedimentation studies of the size and shape of DNA. F. molec. Biol., 11, 373-390.

sutron, W. D. 1971. A crude nuclease preparation suitable for use in DNA reassociation experiments. Biochem. Biophys. Acta, 240, 522-531.

ULLMAN, J. s., AND MCCARTHY, B. J. 1973. The relationships between mismatched base pairs and the thermal stability of DNA duplexes. Biochem. Biophys. Acta, 294, 405-415.

WALKER, P. M. B. 1971. Origin of satellite DNA. Nature, 229, 306-308.

WETMUR, J. G., AND DAVIDSON, N. 1968. Kinetics of reassociation of DNA. 7. molec. Biol., 31, $349-370$

wilson, D. A., AND thomas, c. A., JR. 1974. Palindromes in chromosomes. F. molec. Biol., $84,115-144$.

WU, J. R., HURN, J., AND BONNER, J. 1972. Size and distribution of the repetitive segments of the Drosophila genome. F. molec. Biol., 64, 211-219.

YUNIS, J. J., AND YASMINEH, w. G. 1971. Heterochromatin, satellite DNA and cell function. Science, 174, 1200-1209. 